University of Nebraska - Lincoln

DigitalCommons@University of Nebraska - Lincoln

2008

\title{
Long-Term Dynamics of Leafy Spurge (Euphorbia esula) and its Biocontrol Agent, Flea Beetles in the Genus Aphthona
}

Diane L. Larson

USGS Northern Prairie Wildlife Research Center, Minnesota Field Station, dlarson@usgs.gov

James B. Grace

USGS National Wetland Research Center, Lafayette, LA, gracej@usgs.gov

Jennifer L. Larson

University of Minnesota, St. Paul

Follow this and additional works at: https://digitalcommons.unl.edu/usgsnpwrc

Part of the Other International and Area Studies Commons

Larson, Diane L.; Grace, James B.; and Larson, Jennifer L., "Long-Term Dynamics of Leafy Spurge (Euphorbia esula) and its Biocontrol Agent, Flea Beetles in the Genus Aphthona" (2008). USGS Northern Prairie Wildlife Research Center. 83.

https://digitalcommons.unl.edu/usgsnpwrc/83

This Article is brought to you for free and open access by the US Geological Survey at DigitalCommons@University of Nebraska - Lincoln. It has been accepted for inclusion in USGS Northern Prairie Wildlife Research Center by an authorized administrator of DigitalCommons@University of Nebraska - Lincoln. 


\title{
Long-term dynamics of leafy spurge (Euphorbia esula) and its biocontrol agent, flea beetles in the genus Aphthona
}

\author{
Diane L. Larson ${ }^{\mathrm{a}, *}$, James B. Grace ${ }^{\mathrm{b}}$, Jennifer L. Larson ${ }^{\mathrm{c}}$ \\ a USGS Northern Prairie Wildlife Research Center, Minnesota Field Station, 100 Ecology Building, 1987 Upper Buford Circle, St. Paul, MN 55108, USA \\ ${ }^{\mathrm{b}}$ USGS National Wetland Research Center, Lafayette, LA, USA \\ ${ }^{\mathrm{c}}$ Deptartment of Ecology, Evolution and Behavior, University of Minnesota, St. Paul, MN, USA
}

\section{A R T I C L E I N F O}

\section{Article history:}

Received 8 May 2008

Accepted 28 July 2008

Available online 3 August 2008

\section{Keywords:}

Aphthona lacertosa

Biocontrol

Euphorbia esula

Flea beetle

Great Plains

\begin{abstract}
A B S T R A C T
Three flea beetle species (Aphthona spp.), first introduced into North America in 1988, have come to be regarded as effective biological control organisms for leafy spurge (Euphorbia esula). The black flea beetles (Aphthona lacertosa and A. czwalinae) in particular have been shown to cause reductions in leafy spurge stem counts in the northern Great Plains, while the brown flea beetle (A. nigriscutis) has persisted and spread, but has not been found to be as effective at controlling leafy spurge. The ability of black flea beetles to control leafy spurge in any given year, however, has been found to vary. To better understand the long-term effects of flea beetle herbivory on leafy spurge, we monitored stem counts of leafy spurge and numbers of black and brown flea beetles at three sites on two National Wildlife Refuges in east-central North Dakota, USA, from 1998 to 2006. Brown flea beetle numbers were observed to be negligible on these sites. Over the 9 years of the study, black flea beetles were seen to spread over the three study sites and leafy spurge stem counts declined substantially on two of the three sites. Even at low densities of spurge, black flea beetle populations persisted, a necessary prerequisite for long-term control. We used structural equation models (SEM) to assess the yearly effects of black flea beetles, soil texture, and refuge site on leafy spurge stem counts over this time period. We then used equations developed from the SEM analysis to explore flea beetle-leafy spurge dynamics over time, after controlling for soil texture and refuge. Yearly effect strength of black flea beetles on leafy spurge was found to be modest, largely owing to substantial spatial variability in control. However, simulation results based on prediction coefficients revealed leafy spurge to be highly responsive to increases in flea beetle populations on average.
\end{abstract}

Published by Elsevier Inc.

\section{Introduction}

Leafy spurge (Euphorbia esula L.; Euphorbiaceae) is an Eurasian perennial that is invasive in many areas of North America, but especially in the rangelands and natural areas of the northern Great Plains (Selleck et al., 1962; Watson, 1985). Introduced as a contaminant of crop seed in the late 1880 s to early 1890s (Dunn, $1985)$, leafy spurge is now on the noxious weed lists of 21 states (USDA Plants data base). Negative effects of leafy spurge on native grassland vegetation and ungulate feeding are well documented (Belcher and Wilson, 1989; Butler and Cogan, 2004; Jordan et al., 2008; Trammell and Butler, 1995).

Biological control of leafy spurge by flea beetles (Aphthona spp.; Coleoptera: Chrysomelidae) in the northern Great Plains began in the late 1980s (Hansen et al., 1997) and is generally considered successful by both private landowners and public land managers (Hodur et al., 2006). There are three species of Aphthona in eastern

\footnotetext{
* Corresponding author. Fax: +1 6126246777

E-mail address: dlarson@usgs.gov (D.L. Larson).
}

North Dakota, where our studies were conducted. The brown flea beetle, A. nigriscutis, is easily distinguishable by its brown color. The two black flea beetles, A. lacertosa and A. czwalinae are indistinguishable in the field. Hereafter, we will refer to the flea beetles as either brown (for A. nigriscutis) or black (for A. lacertosa/czwalinae). The density of leafy spurge plants has declined by as much as $95 \%$ after 4 years of herbivory by black flea beetles (Lym and Nelson, 2000) but the degree of control has been observed to vary substantially between different sites (Butler et al., 2006; Kalischuk et al., 2004). This variation has been attributed to locality characteristics such as soil texture, spring warming, density of leafy spurge, and presence of soil-borne pathogens (Caesar, 1996; Jacobs et al., 2001; Kalischuk et al., 2004; Lym, 2005).

Larson and Grace (2004) used multivariate statistical techniques to show that brown flea beetles had no measurable effect on stem density while black flea beetles caused a small and variable decline in stem density of leafy spurge in western North Dakota over a 3-year period. Five years later, observations of the same plots showed that leafy spurge stem densities declined significantly (D. Larson, unpublished data) suggesting that an extended 
time series of flea beetle and leafy spurge data is needed to separate temporal variability in population dynamics from other factors potentially limiting leafy spurge populations.

In addition to the temporal variability in impacts of beetles on spurge, the persistence of flea beetle populations at low host population density has not yet been evaluated. As leafy spurge declines to the levels that are low enough to be acceptable to land managers, flea beetle populations may decline below viable persistence thresholds, ultimately allowing spurge to rebound. McFadyen (1998) proposed that biological control agents should be assessed for success 10-20 years after the last releases of the agents, yet, long-term studies of biological control and target weed population dynamics are rare. In this study, we investigated the dynamics of the Aphthona spp. and leafy spurge by analyzing records from 1998 to 2006 of the annual abundance of the plants and the beetles on wildlife refuges in east-central and southeastern North Dakota. Specifically, we investigated: (1) trends in leafy spurge and flea beetle abundance over this time period; (2) the persistence of the flea beetle populations at low spurge densities; and (3) the capacity of flea beetles to control spurge. Because the data records represented a somewhat heterogenous collection of plot observations (see Section 2, and Table 2), our approach was to fit the data to models of spurge-flea beetle dynamics and to evaluate the resulting coefficients for significance and magnitude (e.g. Hilborn and Mangel, 1997).

\section{Methods}

\subsection{Study sites}

The study was conducted at three sites, at Arrowwood West (AW; $47^{\circ} 16^{\prime} 46.65^{\prime \prime} \mathrm{N}, 98^{\circ} 50^{\prime} 50.00^{\prime \prime} \mathrm{W}$ ) and at Grasshopper Hills (GH; $\left.47^{\circ} 11^{\prime} 18.81^{\prime \prime} \mathrm{N}, 98^{\circ} 47^{\prime} 24.62^{\prime \prime} \mathrm{W}\right)$ of Arrowwood National Wildlife Refuge in east-central North Dakota, and at Tewaukon National Wildlife Refuge (TE; 46 $04^{\prime} 52.86^{\prime \prime} \mathrm{N}, 96^{\circ} 56^{\prime} 59.91^{\prime \prime} \mathrm{W}$ ) in southeastern North Dakota. Mean annual precipitation at weather stations near Arrowwood and Tewaukon is $421 \mathrm{~mm}$ and $495 \mathrm{~mm}$, respectively (High Plains Climatology Network, http:// www.hprcc.unl.edu/data/historical/, for Courteney, ND and Victor, SD, respectively). Precipitation at Arrowwood was $5.7 \mathrm{~mm}$ below the mean and at Tewaukon was $65.5 \mathrm{~mm}$ above the mean at each weather station for the period of our study. Soil texture was measured by the hydrometer method (Day, 1965) and plant-available nitrogen was measured as nitrogen mineralization rates in laboratory incubations (Robertson et al., 1999). Black and brown flea beetles had been released at the study sites, beginning in 1991 at GH, 1994 at AW and 1995 at TE (Table 1). Additional releases, as well as collections for redistribution, of black flea beetles were made in subsequent years in areas adjacent to our study sites at Arrowwood Refuge.

Study plots were established in spring 1998 using a geographically stratified random design so that plots were distributed throughout each study site. In 2004, as leafy spurge became sparse, plots were added at each sample site to increase the sample size (see Table 2, for sample sizes). The permanent plots for leafy spurge stem counts were $0.5 \times 2.0 \mathrm{~m}$ vegetation plot. Aphthona spp. were monitored in an adjacent sweep plot (see Section 2.3). Because the study sites varied in size, different numbers of plots were monitored at each site. The number of plots sampled in each year also varied with changing availability of funding over the years (see Table 2).

\subsection{Leafy spurge density}

To assess the density and distribution of spurge, leafy spurge seedlings (i.e. plants with cotyledons still present), vegetative (nonflowering) stems, and flowering stems from the current growing season were counted in each plot. Due to the abundance of spurge plants on most sites in the first 3-4 years of the study, we counted the number of vegetative and flowering stems and seedlings in a $12.5 \times 50 \mathrm{~cm}$ subunit of the permanent plots at $\mathrm{GH}$ and AW and in a $25 \times 50 \mathrm{~cm}$ subunit at TE, where spurge density was lower. As spurge density declined, we sampled larger areas of the plot in order to obtain better estimates of plant densities. All counts were standardized to the same sample area for analysis by expressing data on a density basis. Sampling was conducted in May-June and August of each year except 1998, when sampling occurred in July only. The structural equation models described below use only the July 1998 and May 1999-2006 counts of mature-sized (vegetative plus flowering) stems. Seedlings were not included in the SEM analysis (see Section 2.4) because of their low survival rate and because they do not provide habitat for flea beetles to overwinter (Selleck et al., 1962).

\subsection{Biological control insects}

Flea beetles were collected with a 38 -cm-diameter sweep net. The sweep plots were sampled three times during the approximate peak of adult emergence in late-June/early-July each year, under conditions believed to be suitable for sampling (clear afternoons with air temperature $>24^{\circ} \mathrm{C}$, wind speed $\leqslant 16 \mathrm{~km} / \mathrm{h}$, and dry vegetation). The highest count obtained was used in subsequent analyses because we assumed it was our best estimator of peak emergence. Because sweeping was potentially damaging to vegetation, sampling was confined to five transects, each approximately $4 \mathrm{~m}$ in length radiating from a central point adjacent to vegetation plots; sampling occurred at a rate of five sweeps per transect. Beetles were counted by species and released at the collection site. In each year, with the exception of 2000 , we counted total numbers of each species of beetle. In 2000, populations of flea beetles had reached such high levels that counts became unreliable and beetle abundance was graded into four categories during this season. These categories were incomparable with counts from other years and were therefore excluded from the analyses of beetle abundance.

\subsection{Statistical analysis}

To evaluate trends in leafy spurge and Aphthona abundance, General Linear Models in SAS v. 9 (SAS Institute Inc., 2003) were

Table 1

Abiotic characteristics of study sites and number of flea beetles released prior to the beginning of the study

\begin{tabular}{|c|c|c|c|c|c|c|c|}
\hline Site & $N$ & Sand (\%) & Clay (\%) & Silt (\%) & Mean net nitrogen mineralization ( $\mu \mathrm{g} N / g$ soil/day) & Black flea beetle & Brown flea beetle \\
\hline AW & 19 & $70.48 \pm 0.89$ & $8.76 \pm 0.41$ & $20.76 \pm 0.68$ & $1.22 \pm 0.08$ & 60,000 & 13,000 \\
\hline $\mathrm{GH}$ & 18 & $73.55 \pm 1.01$ & $7.54 \pm 0.46$ & $18.91 \pm 0.77$ & $0.92 \pm 0.08$ & 216,500 & 14,500 \\
\hline TE & 22 & $89.83 \pm 0.91$ & $4.19 \pm 0.42$ & $5.98 \pm 0.70$ & $0.50 \pm 0.08$ & 146,000 & 0 \\
\hline
\end{tabular}

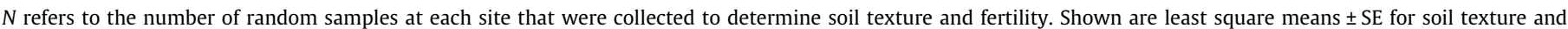
nitrogen mineralization rate. Flea beetles were released throughout the sites. 
Table 2

Number of plots sampled and percentage of plots occupied by black flea beetles and leafy spurge seedlings and/or mature stems, 1998-2006

\begin{tabular}{|c|c|c|c|c|c|c|c|c|c|}
\hline \multirow[t]{2}{*}{ Year } & \multicolumn{3}{|c|}{ Arrowwood West } & \multicolumn{3}{|c|}{ Grasshopper Hills } & \multicolumn{3}{|c|}{ Tewaukon } \\
\hline & $N$ & Black flea beetle (\%) & Spurge (\%) & $N$ & Black flea beetle (\%) & Spurge (\%) & $N$ & Black flea beetle (\%) & Spurge (\%) \\
\hline 1998 & 94 & 66 & 95 & 47 & 72 & 81 & 42 & 64 & 50 \\
\hline 1999 & 95 & 100 & 82 & 48 & 100 & 79 & 42 & 98 & 62 \\
\hline 2000 & 95 & 100 & 54 & 48 & 100 & 52 & 42 & 100 & 19 \\
\hline 2001 & 40 & 100 & 65 & 38 & 100 & 55 & 39 & 82 & 44 \\
\hline 2002 & 39 & 90 & 41 & 33 & 79 & 24 & 40 & 75 & 43 \\
\hline 2003 & 39 & 92 & 41 & 33 & 94 & 72 & 38 & 95 & 53 \\
\hline 2004 & 114 & 68 & 51 & 54 & 59 & 76 & 56 & 82 & 73 \\
\hline 2005 & 108 & 83 & 62 & 49 & 82 & 12 & 52 & 56 & 33 \\
\hline 2006 & 110 & 96 & 23 & 50 & 82 & 24 & 56 & 84 & 43 \\
\hline
\end{tabular}

used to compare yearly mean numbers of vegetative and flowering stems and seedlings (which were omitted from the SEM analyses); and the means of the highest counts each season of brown and black flea beetles. All counts were In-transformed for analysis. The percentage of plots on which leafy spurge and black flea beetles were found each year is shown, without statistical analysis, to illustrate spread and persistence across the study sites.

The effect of black flea beetles on leafy spurge stem counts was estimated using a dynamic model in which black flea beetle and leafy spurge numbers in a given year were functions of their numbers in the previous and current years, while controlling for site and soil texture effects (Fig. 1). While all the individual arrows are not shown in Fig. 1, beetles and spurge were allowed to be dependent on the spatially varying effects of site and soil texture.

The above described model comprised four equations:

$S_{t 0}=\alpha_{1 S 0} T_{1}+\alpha_{2 S 0} T_{2}+\beta_{1} R_{j}+\varepsilon_{1}$

$B_{t 0}=\gamma_{1} S_{t o}+\alpha_{1 B 0} T_{1}+\alpha_{2 B 0} T_{2}+\beta_{1} R_{j}+\varepsilon_{2}$

$S_{t 1}=\gamma_{2} S_{t 0}+\gamma_{3} B_{t o}+\alpha_{1 S 1} T_{1}+\alpha_{2 S 1} T_{2}+\beta_{1} R_{j}+\varepsilon_{3}$

$B_{t 1}=\gamma_{4} B_{t 0}+\gamma_{5} S_{t 1}+\alpha_{1 B 1} T_{1}+\alpha_{2 B 1} T_{2}+\beta_{1} R_{j}+\varepsilon_{4}$

where $S_{\mathrm{to}}$, log spurge stem density at time $0 ; T_{1}$, soil texture component 1 (sand); $T_{2}$, soil texture component 2 (clay); $R_{\mathrm{j}}$, refuge (the site variable); $B_{\mathrm{t} 0}, \log$ beetle density at time $0 ; S_{\mathrm{t} 1}, \log$ spurge stem den-
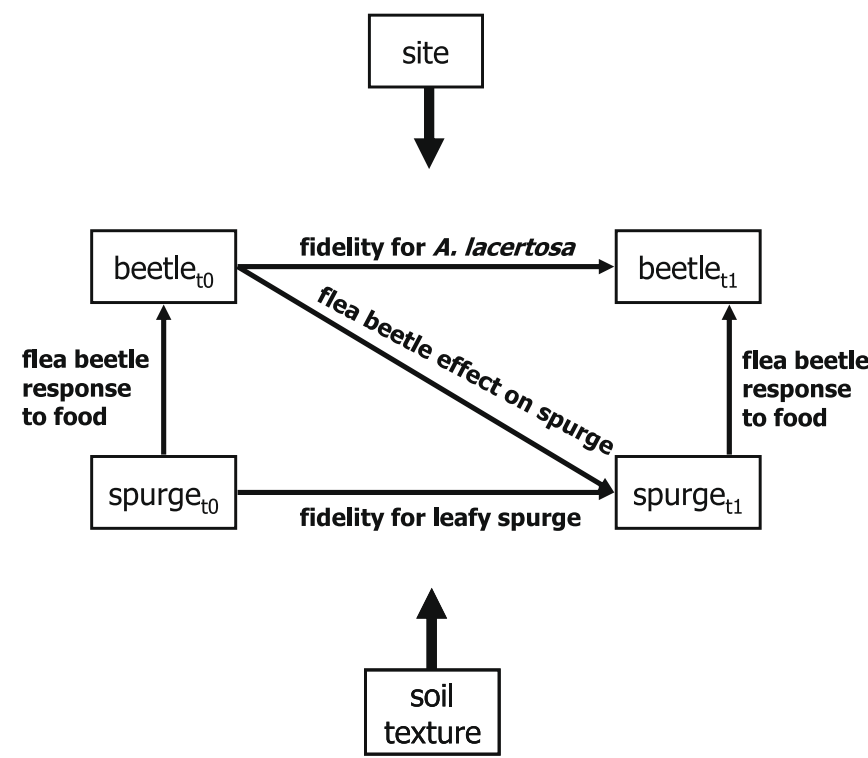

Fig. 1. Proposed model for leafy spurge-flea beetle dynamics with effects of site and soil texture controlled. Beetle $\mathrm{t}_{\mathrm{t} 0}$ and beetle $\mathrm{t}_{\mathrm{t}}$ refer to the number of black flea beetles in years 0 and 1 , respectively. Spurge ${ }_{t 0}$ and spurge $e_{t 1}$ refer to the numbers of mature spurge stems in years 0 and 1 , respectively. sity at time $1 ; B_{\mathrm{t} 1}, \log$ beetle density at time 1 , and other symbols represent various coefficients to be estimated. Examination of temporal dynamics for each plot over the 9 years revealed that plots were not synchronous and that there was no coherent year effect on responses, so year was not included in the model.

The software Amos 7.0 (Arbuckle, 2006) was used to run the model using the above data. As its default, Amos 7.0 implements a full-information maximum likelihood method that is well suited for dealing with missing data (Arbuckle, 1996), which in this case were missing by design (i.e. additional plots were added during the 9 years of the study). As a preliminary stage of the SEM analysis, distributional properties of all variables were examined, as were the shapes and properties of bivariate relationships. Both black flea beetle and leafy spurge densities were $\log$ transformed $[\ln (y+1)]$ to improve distributional properties and to linearize associations. Model fit to data was evaluated using the procedures described in Grace (2006, Chapter 5). To further evaluate the stability of results from the maximum likelihood analysis, while relaxing distributional assumptions somewhat, we also estimated parameters using Markov Chain Monte Carlo (hereafter MCMC) simulations and Amos 7.0 (see Lee, (2007) for a discussion of SEM under MCMC). In this analysis we used a burn-in of 500 simulations and allowed the sampling process to run until the convergence criterion was less than 1.002 . The posterior predictive $p$ was examined to judge model adequacy (Meng, 1994).

\section{Results}

\subsection{Soil characteristics of study sites}

Soil texture varied among sites, with TE having the highest percentage of sand and the lowest nitrogen mineralization rates (Table 1). The percentage of clay at AW was nearly twice that at TE; GH was intermediate in all three measures of soil texture (Table 1 ).

\subsection{Trends}

By 1999, black flea beetles occurred on all but one plot across the three study sites (Table 2) and they have persisted at all sites throughout the nine years of the study (Fig. 2) (the peak in numbers in 2000 is not shown because no counts were made). Brown flea beetle populations never reached a size that would reasonably be expected to impact leafy spurge growth (see Fig. 2). Stem counts of mature leafy spurge plants were highest at the beginning of the study (1998) at AW and GH ( $p<0.002$ or less for all pairwise tests between 1998 and 1999-2006; Table 3). Leafy spurge was never as abundant at TE as at the other two sites, and stem counts in 1998 were not statistically different from counts in $2006(p=0.1496)$ (Fig. 2 and Table 3). After declining in 1999 at AW and GH, leafy spurge stem counts did not decline further in 2000 (Fig. 2), although the plant occupied fewer plots that year than in 

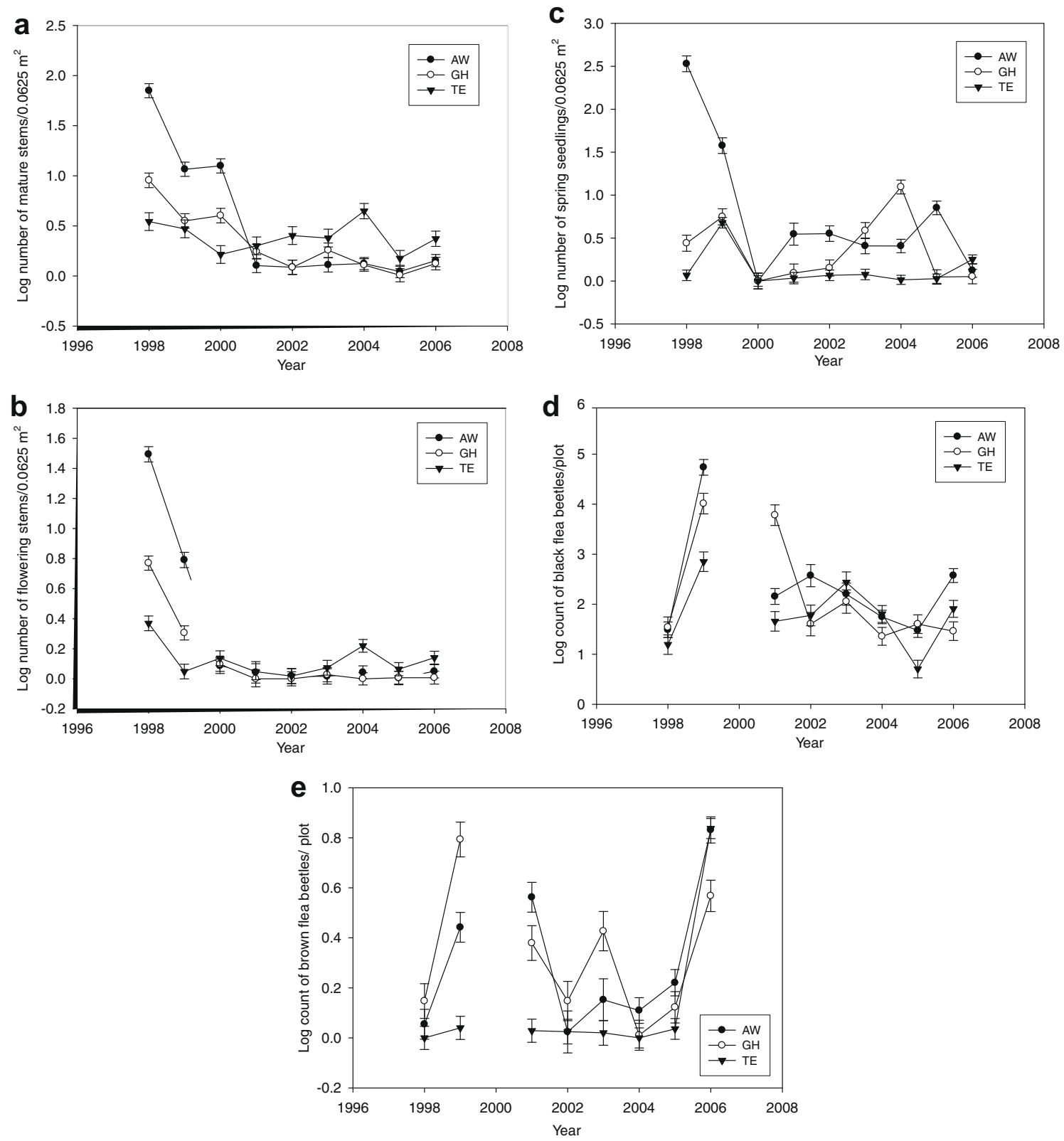

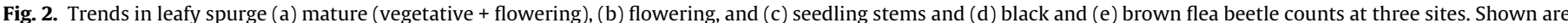

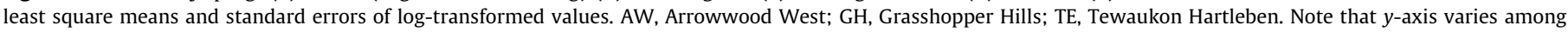
plots.

1998-99 (Table 2). After 2001, leafy spurge numbers remained steady, averaging 1.8 (range 0.73-2.7) and 2.4 (range 0.12-4.7) back-transformed mature stems $\mathrm{m}^{-2}$ at $\mathrm{AW}$ and $\mathrm{GH}$, respectively. Leafy spurge stem counts were higher and more variable at TE, averaging 7.6 (range 3.1-14.6) back-transformed mature stems $\mathrm{m}$ ${ }^{-2}$. There was a decline in the number of flowering stems; backtransformed least-square means 2001-2006 are 0.47, 0.11, and 1.6 flowering stems $\mathrm{m}^{-2}$ at $\mathrm{AW}, \mathrm{GH}$ and TE respectively, compared with peak values in 1998 of 55.2, 18.5, and 7.1 flowering stems $\mathrm{m}^{-2}$ at $\mathrm{AW}, \mathrm{GH}$, and TE, respectively. High values for seedling counts in 2004 at GH and 2005 at AW correspond to years in which prescribed fire was applied to the sites in spring.

\subsection{SEM analysis}

Analysis results indicated acceptable fit between data and model (Model $\chi^{2}=2.60$, with $1 \mathrm{df}, p=0.107, n=2025$. Note: $p$-values above 0.05 indicate acceptable fit in SEM models). To ensure that no pathways were missing, stability tests were conducted by adding and deleting pathways. Results from this evaluation showed no indication of model misspecification. Further, the use of MCMC procedures (as typically used in Bayesian analyses) found results that were virtually identical (within three decimal places) to those obtained via maximum likelihood (ML). This finding indicates that assumptions regarding parameter distributions associated with ML were justified. The posterior predictive $p$ index derived from the MCMC analysis had a value of 0.51 , extremely close to the recommended value of 0.50 .

While most of the site and soil texture (covariate) effects were statistically significant (Table 3 ), a few were not. After controlling for site and soil texture, it was determined that the coefficients associated with the pathways of primary interest in Fig. 1 were all significant (Table 4). Numbers of black flea beetles depended on their food supply (leafy spurge) and numbers the previous year, 
Table 3

Results of general linear models analyses for differences in soil properties among sites and for differences in leafy spurge density and flea beetle density among years and sites

\begin{tabular}{llrccc}
\hline Variable & Source & df & Type III SS & \multicolumn{1}{l}{ Pr } & Pr $F$ \\
\hline \% Sand & Area & 2 & 4576.34714 & 124.91 & $<.0001$ \\
\% Silt & Area & 2 & 2842.741857 & 132.28 & $<.0001$ \\
\% Clay & Area & 2 & 205.6653852 & 26.53 & $<.0001$ \\
Net $N$ mineralization & Area & 2 & 12.65150856 & 28.64 & $<.0001$ \\
In mature stems & Area & 2 & 17.3040301 & 17.27 & $<.0001$ \\
& Year & 8 & 225.3486118 & 56.21 & $<.0001$ \\
& Year *area & 16 & 149.5649297 & 18.65 & $<.0001$ \\
In flowering stems & Area & 2 & 13.3121352 & 30.01 & $<.0001$ \\
& Year & 8 & 155.6078669 & 87.7 & $<.0001$ \\
& Year *area & 16 & 73.6487607 & 20.75 & $<.0001$ \\
In seedlings & Area & 2 & 170.421795 & 124.29 & $<.0001$ \\
& Year & 8 & 248.8573189 & 45.37 & $<.0001$ \\
& Year *area & 16 & 352.19485 & 32.11 & $<.0001$ \\
Black flea beetles & Area & 2 & 105.823206 & 18.59 & $<.0001$ \\
& Year & 7 & 1185.383594 & 59.5 & $<.0001$ \\
& Year *area & 14 & 387.428026 & 9.72 & $<.0001$ \\
Brown flea beetles & Area & 2 & 13.5901572 & 20.82 & $<.0001$ \\
& Year & 7 & 116.4230981 & 50.96 & $<.0001$ \\
& Year * area & 14 & 32.4256263 & 7.1 & $<.0001$ \\
\hline
\end{tabular}

and leafy spurge stem counts were positively associated with counts the previous year (Table 4 and Fig. 3). However, variance explanation $\left(R^{2} \mathrm{~s}\right)$ for response variables ranged from moderate $\left(R^{2}=0.43\right.$ for black flea beetles in year 1$)$ to weak $\left(R^{2}=0.19\right.$ for leafy spurge in year 1 ).

\subsection{Dynamic simulations}

Using the parameter estimates derived from the SEM analysis and Eqs. (1)-(4) above, we performed dynamic simulations to determine the predicted dynamics for the simple case where black flea beetles colonize established stands of leafy spurge. No additional recolonization of recovering spurge by black flea beetles was allowed in our simulations, thus spatio-temporal dynamics were not considered. Representative results from these simulations are illustrated in Fig. 4. These predicted dynamics are generally similar to those at our study sites, although the modeled

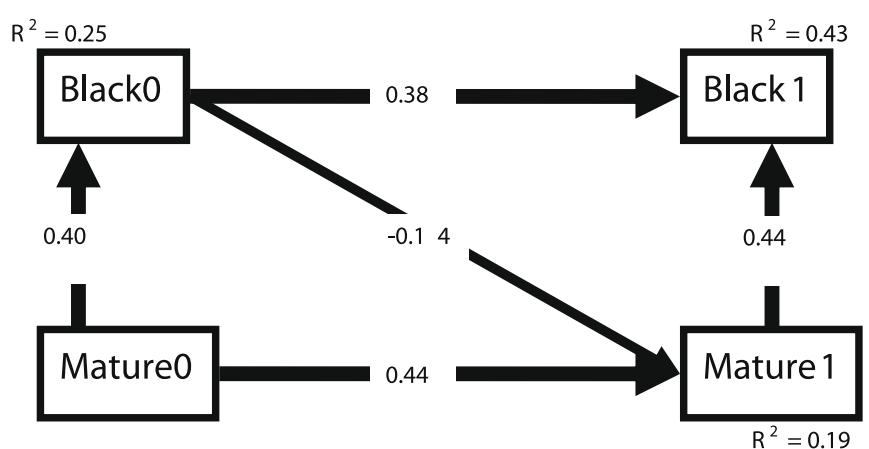

Fig. 3. Model results for interactions between leafy spurge and black flea beetles after controlling for effects of site and soil texture. Numbers superimposed on the arrows refer to the standardized path coefficient (see Grace and Bollen, 2005, for further details on interpretation). The model was consistent with the data $\left(\chi^{2}=2.6\right.$, $\mathrm{df}=1, p=0.107$; note that a $p$ value $>0.05$ indicates consistency between the model and the data). Variables are as in Fig. 1.

relationships lack some of the complexity evident in the empirical data. Nonetheless, these results make it clear that the seemingly small effect of black flea beetles based on the standardized coefficients in Fig. 3 belies the potential for substantial declines in leafy spurge stem counts over time (Fig. 4).

\section{Discussion}

\subsection{Trends}

Our three study sites had been targeted for biological control because of their large populations of leafy spurge, and varying numbers of flea beetles had been released at these sites prior to the start of this study. Between 1998 and 1999 black flea beetles spread throughout our study sites, and their numbers continued to increase through the spring of 2000 , after which both host plant and herbivore declined within 2 or 3 years to levels that have remained low through 2006 at AW and GH. Leafy spurge numbers have been variable at TE, but have not shown an increasing trend overall. The fact that flea beetles have persisted and leafy spurge stem counts have remained low over the course of the last 6 years (for a total of 11-16 years post-release) suggests that biological control can produce long-term reductions (or at least, stability) of leafy spurge in the areas we studied.

Table 4

Parameter estimates (unstandardized path coefficients), their standard errors, and significance levels for model pathways

\begin{tabular}{|c|c|c|c|}
\hline Main pathways & Unstandard coefficient & SE & $p$-Values \\
\hline Spurge year $0 \rightarrow$ black flea beetle year 0 & 0.964 & 0.063 & $* * *$ \\
\hline Spurge year $0 \rightarrow$ spurge year 1 & 0.449 & 0.03 & $* * *$ \\
\hline Black flea beetle year $0 \rightarrow$ black flea beetle year 1 & 0.387 & 0.027 & $* * *$ \\
\hline Black flea beetle year $0 \rightarrow$ spurge year 1 & -0.06 & 0.014 & $* * *$ \\
\hline Spurge year $1 \rightarrow$ black flea beetle year 1 & 1.064 & 0.057 & $* * *$ \\
\hline \multicolumn{4}{|l|}{ Covariate (site and texture) effects } \\
\hline Site $\rightarrow$ spurge year 0 & -0.196 & 0.155 & 0.208 \\
\hline Site $\rightarrow$ black flea beetle year 0 & -2.572 & 0.337 & $* * *$ \\
\hline Site $\rightarrow$ spurge year 1 & -0.396 & 0.16 & 0.013 \\
\hline Site $\rightarrow$ black flea beetle year 1 & -1.393 & 0.351 & $* * *$ \\
\hline$\%$ Sand $\rightarrow$ spurge year 0 & 0.033 & 0.011 & 0.003 \\
\hline$\%$ Sand $\rightarrow$ black flea beetle year 0 & 0.131 & 0.024 & $* * *$ \\
\hline$\%$ Sand $\rightarrow$ spurge year 1 & 0.035 & 0.011 & 0.002 \\
\hline$\%$ Sand $\rightarrow$ black flea beetle year 1 & 0.048 & 0.025 & 0.055 \\
\hline$\%$ Clay $\rightarrow$ spurge year 0 & 0.069 & 0.027 & 0.01 \\
\hline$\%$ Clay $\rightarrow$ black flea beetle year 0 & 0.165 & 0.058 & 0.005 \\
\hline$\%$ Clay $\rightarrow$ spurge year 1 & 0.055 & 0.026 & 0.034 \\
\hline$\%$ Clay $\rightarrow$ black flea beetle year 1 & 0.041 & 0.058 & 0.481 \\
\hline
\end{tabular}

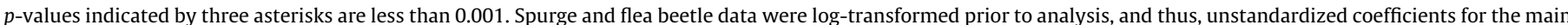
pathways can be interpreted as predicted proportional changes. 


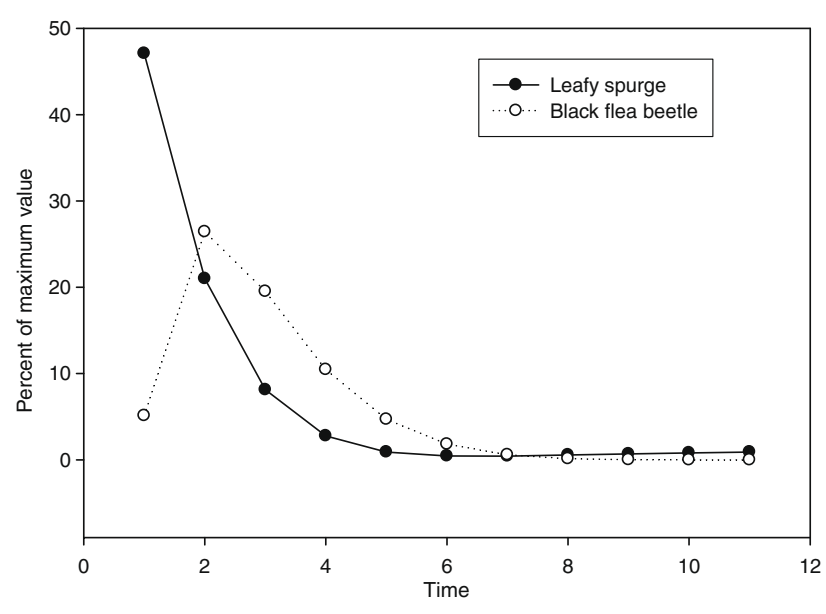

Fig. 4. Simulated results for leafy spurge stem counts and black flea beetle abundance over time. Values for both leafy spurge and black flea beetles are lntransformed. The $y$-axis applies to both leafy spurge and flea beetles; values were divided by the maximum value for each so the two lines could be shown on approximately the same scale.

Butler et al. (2006) also found that black flea beetles increased rapidly during the first 2-3 years of their study in Montana and South Dakota, and produced significant reduction in leafy spurge populations during the subsequent 4 years at both release and nonrelease sites they monitored. We note that flea beetle releases and removals have been made in the vicinity of both AW and GH (though not at TE) and movement into and out of our study areas is possible as a result of these management actions, despite the generally low dispersal rates documented for black flea beetles (Lym and Nelson, 2000; Van Hezewijk and Bourchier, 2005). Thus, our study does not rule out the possible need to subsidize flea beetle populations at low host plant densities if control is to be maintained.

Our results are consistent with others who have found that flea beetles are less effective at controlling leafy spurge at sandy sites (Lym, 2005). Soil texture at TE was much sandier than at the other two sites, and although flea beetles have become established there, and their numbers are comparable to those we found at AW and $\mathrm{GH}$, spurge stem counts have not been reduced to the same extent that they have been at AW and GH. While leafy spurge stem counts have not increased at TE, our study cannot conclusively attribute the cause to the presence of flea beetles because a flea beetle-free control site is lacking.

\subsection{Plant-herbivore interactions}

The mean yearly standardized effect strength of black flea beetles on leafy spurge at our study sites was a modest -0.14 . This effect size is even smaller than the one found previously for leafy spurge and Aphthona flea beetles in western North Dakota $(-0.23)$ (Larson and Grace, 2004). Such standardized effects represent measures of the degree of association averaged across the total range of situations, including those plots in which beetles have not yet colonized and those plots in which beetles have already reduced spurge densities. Simulations (Fig. 4), in contrast, reflect the potential effect of beetles on spurge in absolute terms when co-occurring in a plot. Under such circumstances, results show that the effects of black flea beetles on spurge can be rapid and dramatic.

One additional point to note is that we found a net positive association between prior and current year stem counts over 9 years of this study, suggesting that reproduction was most likely to occur in the vicinity of existing spurge patches. This positive association likely results from vegetative reproduction, which is common in leafy spurge, especially when apical buds are damaged
(Selleck et al., 1962). In a previous study, Larson and Grace (2004) found that flower production declined substantially as black flea beetles increased and leafy spurge stem counts declined, which they attributed to stress imposed by herbivory. Likewise, sexual reproduction had declined markedly by the final years of this study. Although leafy spurge seedbanks may remain viable for as many as 13 years (Selleck et al., 1962), if prescribed fires typically result in a flush of germination, as anecdotally noted in our study, it may be possible to substantially reduce the seedbank over time through a combination of stress induced by flea beetle herbivory and promotion of germination via fire. We have no evidence that the flush of seedlings resulted in increased numbers of adult stems the following year (adult stems did not differ significantly between the number recorded in the year of the burn and the number recorded the year after the burn; $p=0.3088$ for log mature stems in 2004 and 2005 at GH and $p=0.1794$ for log mature stems in 2005 and 2006 at AW), and seedling numbers were notably low in the years following these two events. Black flea beetle numbers were stable following the prescribed fires, but it is important to note that fire must be applied when adult flea beetles are not active. Fellows and Newton (1999) found that fires applied in May or October in eastern ND did not harm brown flea beetle colonies; they did not test effects on black flea beetles.

\subsection{Conclusion and management implications}

Dynamics of black flea beetles and leafy spurge varied substantially among study sites and years, yet our simulation demonstrates that the mean negative effect of the flea beetles on leafy spurge is sufficient for control over the long-term. The inherent spatial and temporal variability in the long-term dynamics is consistent with variation in control observed by others (Butler et al., 2006; Kalischuk et al., 2004). Therefore, we join those that encourage a strategy of adaptive management (Shea et al., 2002) and recognition that strategic redistribution of biocontrol insects may be necessary, especially as the host population declines to the low levels that are the goal of classical biological control. Land managers should feel encouraged that black flea beetles have not only established but have persisted over 11-16 years, even at a site with suboptimal, sandy soils. Finally, we would encourage further investigation into the possibility of reducing the leafy spurge seedbank via combined use of biological control to reduce seed production and control seedling survival, and carefully timed prescribed fire to encourage germination of the existing seedbank without injury to the flea beetle population.

\section{Acknowledgments}

Logistical support for this study was generously provided by the US Fish and Wildlife Service; we especially thank P. Scherr and K. Askerooth for their insight into management at their refuges. We thank J. Hoffmann for editorial advice that improved the clarity of the paper. D. Buhl, R. Gleason, N. Jordan and two anonymous reviewers provided valuable comments on earlier versions of this manuscript. Financial support was provided by USGS and Northern Prairie Wildlife Research Center. Any use of trade, product, or firm names is for descriptive purposes only and does not imply endorsement by the US Government.

\section{References}

Arbuckle, J.L., 1996. Full information estimation in the presence of incomplete data. In: Marcoulides, G.A., Schumacker, R.E. (Eds.), Advanced Structural Equation Modeling. Lawrence Erlbaum Associates, Mahwah, NJ.

Arbuckle, J.L., 2006. Amos 7.0 User's Guide. Amos Development Corporation. Spring House, PA, USA. 
Belcher, J.W., Wilson, S.D., 1989. Leafy spurge and the species composition of a mixed-grass prairie. Journal of Range and Management 42, 172-175.

Butler, J.L., Cogan, D.R., 2004. Leafy spurge effects on patterns of plant species richness. Journal of Range Management 57, 305-311.

Butler, J.L., Parker, M.S., Murphy, J.T., 2006. Efficacy of flea beetle control of leafy spurge in Montana and South Dakota. Rangeland Ecology \& Management 59, 453-461.

Caesar, A.J., 1996. Identity, pathogenicity and comparative virulence of Fusarium spp. related to stand declines of leafy spurge (Euphorbia esula) in the northern plains. Plant Disease 80, 1395-1398.

Day, P.R., 1965. Particle fractionation and particle size analysis. In: Black, C.A. (Ed.), Methods of Soil Analysis. Part 1. American Society of Agronomy and Soil Science Society of America, Madison, WI, pp. 545-567.

Dunn, P.H., 1985. Origins of leafy spurge in North America. In: Watson, A.K. (Ed.), Leafy Spurge. The Weed Science Society of America, Champaign, IL, pp. 7-13.

Fellows, D.P., Newton, W.E., 1999. Prescribed fire effects on biological control of leafy spurge. Journal of Range Management 52, 489-493.

Grace, J.B., Bollen, K.A., 2005. Interpreting the results from multiple regression and structural equation models. Bulletin Ecology Society of America 86, 283-295.

Grace, J.B., 2006. Structural Equation Modeling and Natural Systems. Cambridge University Press, Cambridge, UK.

Hansen, R.W., Richard, R.D., Parker, P.E., Wendel, L.E., 1997. Distribution of biological control agents of leafy spurge (Euphorbia esula L.) in the United States: 1988-1996. Biological Control 10, 129-142.

Hilborn, R., Mangel, M., 1997. The Ecological Detective: Confronting Models with Data. Princeton University Press, Princeton, NJ.

Hodur, N.M., Leistritz, F.L., Bangsund, D.A., 2006. Biological control of leafy spurge: utilization and implementation. Range land Ecology \& Management 59, 445452 .

Jacobs, J.S., Sheley, R.L., Spencer, N.R., Anderson, G., 2001. Relationships among edaphic, climatic, and vegetation conditions at release sites and Aphthona nigriscutis population density. Biological Control 22, 46-50.

Jordan, N.R., Larson, D.L., Huerd, S.C., 2008. Soil modification by invasive plants: effects on native and invasive species of mixed-grass prairies. Biological Invasions $10,177-190$.
Kalischuk, A.R., Bourchier, R.S., McClay, A.S., 2004. Post hoc assessment of an operational biocontrol program: efficacy of the flea beetle Aphthona lacertosa Rosenhauer (Chrysomelidae: Coleoptera), an introduced biocontrol agent for leafy spurge. Biological Control 29, 418-426.

Larson, D.L., Grace, J.B., 2004. Temporal dynamics of leafy spurge (Euphorbia esula) and two species of flea beetles (Aphthona spp.) used as biological control agents. Biological Control 29, 207-214.

Lee, S.Y., 2007. Structural Equation Modeling: A Bayesian Approach. John Wiley and Sons, West Sussex, UK.

Lym, R.G., 2005. Integration of biological control agents with other weed management technologies: successes from the leafy spurge (Euphorbia esula) IPM program. Biological Control 35, 366-375.

Lym, R.G., Nelson, J.A., 2000. Biological control of leafy spurge (Euphorbia esula) with Aphthona spp. along railroad right-of-ways. Weed Technology 14, 642646.

McFadyen, R.E.C., 1998. Biological control of weeds. Annual Review of Entomology 43, 369-393.

Meng, X.L., 1994. Posterior predictive $p$-values. Annals of Statistics 22, 1142-1160

Robertson, G.P. Coleman, D.C., Bledsoe, C.S., Sollins, P. (Eds.), 1999. Standard Soil Methods for Long-term Ecological Research. Oxford University Press Inc., New York, NY.

SAS Institute Inc., Software Version 9.1. SAS Institute, Inc., Cary, North Carolina, USA 2003.

Selleck, G.W., Coupland, R.T., Frankton, C., 1962. Leafy spurge in Saskatchewan. Ecological Monographs 32, 1-29.

Shea, K., Possingham, H.P., Murdoch, W.W., Roush, R., 2002. Active adaptive management in insect pest and weed control: intervention with a plan for learning. Ecological Applications 12, 927-936.

Trammell, M.A., Butler, J.L., 1995. Effects of exotic plants on native ungulate use of habitat. Journal of Wildlife Management 59, 808-816.

Van Hezewijk, B.H., Bourchier, R.S., 2005. Is two company or a crowd: how does conspecific density affect the small-scale dispersal of a weed biocontrol agent? Biocontrol Science Technology 15, 191-205.

Watson, A.K. (Ed.), 1985. Leafy Spurge. Weed Science Society of America, Champaign, IL. 